See discussions, stats, and author profiles for this publication at: https://www.researchgate.net/publication/319292611

\title{
Activating citizens in Dutch care reforms: Framing new co-production roles and competences for citizens and professionals
}

Article in Policy \& Politics · August 2017

DOI: 10.1332/030557317X15035697297906

\section{CITATIONS}

3

2 authors:

José Nederhand

Erasmus University Rotterdam

13 PUBLICATIONS 50 CITATIONS

SEE PROFILE
188

Ingmar Van Meerkerk

Erasmus University Rotterdam

51 PUBLICATIONS 290 CITATIONS

SEE PROFILE

Some of the authors of this publication are also working on these related projects:

Community self-organization: cross-country survey research View project

Project Boundary Spanning in community driven Urban Regeneration View project 


\title{
Activating citizens in Dutch care reforms: framing new co-production roles and competences for citizens and professionals
}

José Nederhand and Ingmar van Meerkerk

To cite this article: Nederhand, M.J. and Van Meerkerk, I. (2017), 'Activating citizens in Dutch care reforms: framing new co-production roles and competences for citizens and professionals', Policy \& Politics, DOI: 10.1332/030557317X15035697297906

To link to this article: https://doi.org/10.1332/030557317X15035697297906

\begin{abstract}
This study explores the growing interest of governments in co-production and self-organisation by examining the framing of roles and responsibilities of citizens and professionals in care reforms. As in many other western countries, the Dutch welfare state is subject to major reforms, shifting responsibilities back towards society. A qualitative content analysis of policy letters of the Dutch national government shows that newer roles (citizen-asco-producers) do not substitute traditional roles (citizen-as-clients), but constitute a new layer resulting in an expansion and diversification of roles for regular providers. Activating, supporting and partnering with citizens are framed as new competences of professionals.
\end{abstract}

Keywords: active citizenship; coproduction; social care; welfare state reform

\section{$1 \quad$ Introduction}

In many Western countries, public service provision is subject to major reforms. Activating citizens through shifting responsibilities 'back to society' or including citizens in the production of public services has increasingly come onto the agenda of policy makers. It is regarded as a possible solution to the public sector's decreased legitimacy and dwindling resources (Brandsen \& Honingh, 2016; Endo and Lim, 2017; Lodge and Hood 2012). In parallel with academic debates, the idea of co-producing and self-organizing public services seems to have penetrated the discourse of politicians and governors all over the world. It is seen as part of a drive to reinvigorate voluntary participation and strengthen social cohesion in an increasingly fragmented and individualized society. 
Existing scholarship predominantly focusses on the theoretical conceptualization of different forms of coproduction, either by theoretical argumentation or by examining experiences in co-production and selforganization (Verschuere et al., 2012; Voorberg et al., 2015). Less attention has been paid to how governments actually frame the co-production and self-organization of public services in reform programs (see for an exception Verhoeven and Tonkens, 2013). In this article, we analyse how governments frame the changing relationship between citizens and regular service produceres in the delivery of services in the context of budget cuts and changing societal demands. The reforms that have taken place in the Dutch care regime during the past four years provide a scenario to empirically examine the framing of the citizenregular provider relationship. This sector, in which citizens have traditionally been targeted as clients, has been subject to major reforms in which emphasis is being put on shifting responsibilities 'back' towards society in order to keep care provision 'affordable, accessible and in line with societal demands' (Appendix, P10). We formulated the following research question: How does the Dutch national government frames the relationship between citizens and regular providers in the production of care services in the period 2012-2015 and how does this contribute to wider understanding of changing care provision?

Next to contributing to our understanding on how governments justify change measures and trying to reshape citizen roles and responsibilities, this research contributes to the literature in two ways. First, as existing scholarship on co-production and self-organization is predominantly based on case-studies (Verschuere et al., 2012; Voorberg et al., 2015), this research responds to recent calls to make the research methodologically more diverse (Brandsen \& Honingh, 2016). By conducting a content analysis, this article examines how governments actually frame the co-production and self-organization of public services in reform programs. Second, in the literature on co-production much attention is paid to the role of citizens, whereas the corresponding role of regular producers in the process remains an understudied topic (Brandsen \& Honingh, 2016). In the analysis, we therefore explicitly focussed on the role of regular service providers vis-à-vis citizens, thereby starting to fill this gap in the literature.

The following sections of this article discusses the literature on co-production and activation of citizens in current welfare state reforms. Next, we discuss our methods followed by the results. The article concludes with some reflections on the new public service ethos of professionals. 


\section{$2 \quad$ Activating citizens: transforming public welfare states?}

Over the last two to three decades, promoting 'active citizenship' has become a key and recurring topic of policy-making and governmental reforms in many Western welfare states (Newman, 2007; Rose, 2006; Verhoeven and Tonkens, 2013). Many of the literature on activation is focused on social services in relation to unemployment (see Borghi and Van Berkel, 2007). The general nature of the discourse in this context is that "citizens are increasingly considered to be responsible for their own lives, are expected to invest in their employability, and, when dependent on the welfare state, are granted rights and entitlements only on the condition that they fulfil the obligations society imposes on them" (Borghi and Van Berkel, 2007: 413414). Discourses of activation have also penetrated other areas such as health care services, liveability and community services. In these areas the state has less capabilities to force citizens to become active: to dedicate their spare time to support others in the community. Through volunteering, citizens are expected to shoulder tasks formerly performed by the state, such as providing support to disadvantaged and vulnerable groups, either by partnering and co-production with the state or by self-organization (Verhoeven and Tonkens, 2013). This implies an explicit departure from the traditional provider-centric model of the welfare state. In fact, the care system is gradually shifting from an orientation on collective solidarity towards one that is predominantly based on individual responsibility (Van Oorschot, 2006; Künzel, 2012).

While research on activation has examined activation policies in relation to new forms of governance (Newman, 2007) and to the individualization trend in the provision of services (Borghi and Van Berkel, 2007), less attention has been paid to the framing of roles and responsibilities in the relationship between citizens and regular service providers. To enhance our understanding of this relationship we draw on two growing bodies of literature in the field of public administration: co-production and self-organization.

\section{Co-producing and self-organizing public service delivery}

The idea of activating citizens in the production of public services is made explicit in the co-production literature. We can distinguish two waves of academic interest in the concept (Bryson et al., 2014; Bovaird et al., 2015). The first wave of interest in co-production started in the 1970s. Early definitions of co- 
production focussed upon the pooling of resources of users and providers to raise the quantity and/or quality of the service (Brudney, 1983; Bovaird et al., 2015). Hence, users and providers thus actively collaborate in the service provision. Recently, a second wave of interest in co-production has been triggered (Verschuere et al., 2012; Bovaird et al., 2015). This attention perfectly fits within the rising scholarly recognition that public outcomes need multiple stakeholders for their realisation. Apart from the recognition that co-production could be a means to effectively address social challenges (Bovaird et al., 2015; Voorberg et al., 2015), there are also more practical reasons for this renewed interest in the potential of co-production. These reasons connect to the fiscal pressures many governments face since 2008. Some scholars suggest that governments eye co-production as a potential vehicle for doing more with less by involving societal resources in service production and delivery (Thomas, 2013; Brandsen et al., 2014). As a result, co-production has been embraced as a new reform strategy for the public sector thereby fundamentally changing the structure of service provision (Osborne and Strokosch, 2013).

Whereas forty years on co-production literature offers a variety of definitions of the concept, the foundational ideas remains the same: citizens are not only required for the consumption of public services but also for the production of these services. Thus, both regular providers and (groups of) citizens contribute to the provision of public services (Pestoff, 2006). Although, there are several definitions and forms of co-production discussed in the literature (see Voorberg et al., 2015), we focus on co-production between professionals and citizens, defined as the development of long term relationships between professionalized service providers and service users, or other members of the community, where all parties make substantial resource contributions and both take an active role in the direct delivery and design of a public service (see Bovaird, 2007:847; Brandsen \& Honingh, 2016). Note that in this definition citizens can be a direct recipient of a service, but need not necessarily be so. For instance, family members or other relatives could also participate in the co-production process for the direct beneficiary (Pestoff, 2012).

Another relevant literature stream to study fundamental changes in the provision of care services, focusses on citizen self-organization. This stream of literature examines citizen initiatives in the production of public services (Edelenbos and Van Meerkerk, 2016; Endo and Lim, 2017; Healey, 2015). These initiatives are sometimes organized as an addition to, but can also be in competition with service delivery by market or government organizations. These bottom-up civic initiatives can arise from dissatisfaction or complaints 
with governmental policy and actions or emerge in spaces that governments withdraw from due to budget cuts (e.g. Van Meerkerk et al., 2013; Wagenaar and Van der Heijden, 2015). The phenomenon of citizen selforganization is, historically speaking, not new, but the current 'wave' is getting shape in a different institutional context in which the role of government in society is stronger than ever and we face the curious situation of the state urging a reluctant citizenry to engage in civil society (Brandsen et al., 2014). The self-organizing paradigm has an explicit focus on an active civil society in which citizens have a leading role in the design and implementation of particular public services. This does not mean public sector professionals are not involved. According to Bovaird (2007) professionals often have at least an indirect role (e.g., advice, quality checks). Moreover, governments can take up a facilitating and/or monitoring role, safeguarding public values (Edelenbos et al., 2017). Citizen self-organization is different from traditional forms of government-centred citizen consultation as citizens determine the content-the subject matter, priorities, and plans-and the processes under which their engagement takes place. Self-organization relates to the initiation, ownership and exploitation of service or product based initiatives by groups of citizens that deal with improving the social and/or physical environment. These civic initiatives take different forms and are emerging in different fields (Edelenbos and Van Meerkerk, 2016). In the field of healthcare, we see for example a rise in care cooperatives, providing community-led care services for older people as a response to severe budget cuts in long-term medical care, social care and care for the elderly. In this manifestation, citizens thus become providers of services themselves, in addition to, or instead of, regular providers.

How do governments frame new relationships between regular providers and citizens in specific care reforms? In the following sections we go deeper into the empirical study we conducted to enhance our understanding of changing relationships and new roles of citizens and regular providers as suggested by the various literature on co-production and self-organization.

\section{$4 \quad$ Content analysis of policy documents}

Dutch care reforms provide a key case, referring to the capacity of a case to exemplify the analytical object of study (Thomas, 2011), to examine the reconceptualization of the roles of citizens and regular providers in current care reforms. We deliberately picked this policy sector, as it is a key sector undergoing intense reforms because of rising expenditures and an ageing population. Moreover, since the rise of the welfare 
state in the Netherlands, this sector has been characterized by strong governmental and professional dominance concerning the design and delivery of public services, and government is now trying to reshape roles and responsibilities in this respect (e.g. Yerkes et al. 2011). Pushed by pressures on the financial sustainability of the current system, the Dutch care system is undergoing substantial reforms, characterized by a so-called 'turnaround' of the system (Movisie, 2015; VNG, 2015). This turnaround implies a more prominent role for informal care in the care system in order to safeguard quality and longterm stability. In this reform, national government is calling upon the personal resources of people and their environments.

This study proceeds from a content analysis of the narratives used in all national governmental policy letters on care and social support in the Netherlands published between January 2012 and December 2015. This was a (run-up) period in which the Dutch care system was reformed consequent to the significant revision of existing regulatory systems (VNG 2015). In our analysis, we focus upon policy letters, as these documents are the pre-eminent site in which national governments motivate and legitimize their policy choices and concrete plans for addressing public care service provision at local, regional and national level. Thereby, national governments communicate visions about the future of government actions and the key topics of interest at the time. Within these documents we focus upon the discursive legitimation that governments use in the presentation of their policies. The usage of particular frames and narratives help sustain the societal support for particular policy programs and measures (Hajer, 2003).

We selected relevant policy letters through the national government's document database in which more than 158,500 national governmental documents are stored. We used different keywords, based on commonly used care jargon to ensure the sensitivity and specificity of the queries, to search for and extract policy documents on care and social support (see Table 1). This search resulted in 1,331 results of which 559 documents were identified as policy letters. These documents were screened for their applicability on the basis of the content of the letters: title, abstract and/or full text. This resulted in 205 search results. For example, policy letters with titles such as 'education for asylum seekers' or 'reaction on questions about priorities in the policy on culture' were excluded. We also excluded policy letters that concerned care services in the Caribbean Netherlands because of the different institutional context. 
The selected documents were read through to make sure that care policies were at the core of the document and not, for instance, mentioned only once in a sub-paragraph.

Excluding duplicates, this process resulted in the selection of 37 policy letters: 4 in 2012, 6 in 2013, 16 in 2014 and 11 in 2015. The large number of duplicates can be explained by the fact that many documents were covered by multiple search terms. In line with our expectations, most documents emanated from the Ministry of Public Health (VWS) (see Appendix for list P1 to P37).

TABLE 1 Overview selection process policy documents

\begin{tabular}{lccc}
\hline Search terms & $\begin{array}{c}\text { Results first } \\
\text { search - } \\
\text { including all } \\
\text { sorts of } \\
\text { documents }\end{array}$ & $\begin{array}{c}\text { Results first } \\
\text { selection - } \\
\text { including } \\
\text { policy letters }\end{array}$ & $\begin{array}{c}\text { Results } \\
\text { second } \\
\text { selection - } \\
\text { based on } \\
\text { content }\end{array}$ \\
\hline Social Support Act + family care & 101 & 45 & 30 \\
Social Support Act + informal care & 100 & 50 & 16 \\
Social Support Act + respite care & 26 & 13 & 9 \\
Social Support Act + voluntary care & 107 & 64 & 22 \\
Long-term Care Act + family care & 41 & 19 & 17 \\
Long-term Care Act + informal care & 51 & 24 & 7 \\
Long-term Care Act + respite care & 19 & 9 & 6 \\
Long-term Care Act + voluntary care & 39 & 17 & 8 \\
Informal care & 358 & 100 & 18 \\
Family care & 191 & 82 & 36 \\
Respite care & 31 & 16 & 10 \\
Voluntary care & 267 & 120 & 26 \\
\hline Total (including duplicates) & 1331 & 559 & 205 \\
Total (excluding duplicates) & & & 37 \\
\hline
\end{tabular}

In this study we conducted a qualitative content analysis. To make valid and replicable inferences, we made use of the step-by-step approach of the constant comparative method (Boeije, 2002). We first segmented our data into relevant categories, by making use of an open coding process. Open coding is the process of breaking down, examining, comparing, conceptualizing and categorizing data (Strauss \& Corbin, 1990). The fragments were then compared among each other, grouped into categories dealing with the same subject, and labelled with a code. The list of codes was then grouped in categories by means of axial coding and reassembled into the findings that are presented in this article. In this process we made use of Atlas.Ti software for qualitative data analysis. 
To ensure the validity of our research, we tested for inter-coder reliability. To conduct this test we selected one policy document per year, for the period 2012-2015, using a randomizer tool (P3, P10, P15 and P36, see Appendix). These four letters, representing over $10 \%$ of the total number of analysed letters, were coded by a second coder. Krippendorff's alpha test (Hayes and Krippendorff 2007) resulted in an average inter-coder reliability coefficient of .83 (range .77 to .89), which indicates good inter-coder reliability. In the coding process, we assigned codes only to sections of the policy letters that fall within our direct research scope of care and social support for people who are not self-sufficient. This excludes for example text sections on child abuse, youth care, ICT, personal budgets, forced marriages, energy savings, administrative burdens, security, healthcare packages and real estate.

\section{$5 \quad$ Framing new roles for citizens and regular providers in public care reform}

Political discourse stresses the involvement of citizens in public service delivery, but how is this translated in governmental policy letters which enlist concrete policy goals and actions? We will now empirically examine the main themes that are present in the policy documents on care and social support. We start with an analysis of the themes that are used for legitimizing the role changes of citizens and regular providers in the production of care services.

\section{Framing the problem(s) and proposed solutions}

Especially in the early period of the reorganization of the care system, national government emphasises the inescapability of reorganizing care provision. For example: "Transformation is required to make care futureproof. The place where we organize care, how we provide care and those who provide the care will change the next few years." (P5, p.2) A strong sense of urgency is created around the necessity of governmental interventions. A typical quote in this respect: "If we don't act now, severe future interventions will become unavoidable." (P10, p.4) A turnaround of the system is needed to safeguard the long-term stability of care provision. The most mentioned reasons to change the current system of care provision are the growth of demand (a growing population of elderly people), but also changing demands to care (societal demands): people want more customized care. Both reasons are connected to the financial sustainability of the current system. The frame that high quality levels of care provision can only be maintained if changes are implemented rapidly to make the system future proof, prevails in the policy letters. This 'change necessity' 
frame is accompanied by policy goals such as: to keep care provision affordable, accessible and in line with changing societal demands.

The turnaround implies the organization of care to shift from "system-centred" towards "people-centred". Within this frame, in which national government emphasises the human dimension, the customization of care is a central theme. Namely, people centred care implies custom-made care provision that matches the needs and abilities of individual citizens and their environments. "In a decentralized system, municipalities can connect to the power in society that differs from place to place." (P14, p.3) In line with societal demands, national government wants individual citizens to live in their own neighbourhood and homes as long as possible. This is also where the activation of citizens as important actors in the production of care services comes in. In order to organize care and social support close to home in a customized way, informal carers should play a substantial role according to government. In this way of working, the national government is calling upon personal resources of people and their environments: a very prominent frame in the policy letters. Hence, a society in which people show concern for others is a necessary condition for the policy to work out.

In Table 2 the different themes are depicted. This data clearly indicate that national government assumes the reorganization of the care system to take place on the system and on the personal level: both professionals and citizens should adapt their roles to make the organizational and delivery of care services future proof. 


\begin{tabular}{|c|c|c|c|}
\hline Category & Code & Results $^{\mathbf{a}}$ & Total \\
\hline \multirow[t]{5}{*}{ Change is necessary } & Sustainability of care & $43 \%(16 / 37)$ & $65 \%(24 / 37)$ \\
\hline & Changing demands & $16 \%(6 / 37)$ & \\
\hline & Safeguard accessibility of care & $22 \%(8 / 37)$ & \\
\hline & Affordability of care & $8 \%(3 / 37)$ & \\
\hline & Quality and continuity of care & $51 \%(19 / 37)$ & \\
\hline \multirow[t]{4}{*}{ System change } & Custom made care & $54 \%(20 / 37)$ & $70 \%(26 / 37)$ \\
\hline & Care organized nearby & $19 \%(7 / 37)$ & \\
\hline & People centred care & $14 \%(5 / 37)$ & \\
\hline & Change/turnaround of positions & $43 \%(16 / 37)$ & \\
\hline \multirow[t]{4}{*}{ Personal change } & Care in own environment & $51 \%(19 / 37)$ & $68 \%(25 / 37)$ \\
\hline & Use of personal resources & $49 \%(18 / 37)$ & \\
\hline & Show concern for each other & $35 \%(13 / 37)$ & \\
\hline & Self-management & $32 \%(12 / 37)$ & \\
\hline
\end{tabular}

a. The results show the percentage of the documents containing the code

In the following sections, we probe the framing of roles and responsibilities of citizens and regular providers in the documents relating to this reform of Dutch care provision by distinguishing five differing narratives (see also Table 3). We subsequently discuss which roles as described in the literature are stressed in these narratives.

\section{Narratives used in policy documents}

\section{Activation narrative}

The activation narrative, which we recognized in $68 \%$ of the analysed policy documents ( 25 of 37 ), is madeup of sentences in which national government explicitly describes the usage of citizen resources in care services as an inextricable, fundamental part of the system of care provision (P1, p.1). Being the dominant frame in only $5 \%$ of the documents ( 2 of 37 ) this narrative is used mainly as a starting point for the other narratives.

In the activation narrative, care provision is primarily depicted as being a responsibility of citizens themselves. 'Government cannot and should not take everything out of its citizens hands' (P1, p.9). Hence, 
within district nurses' care assessment, the capacity of citizens and informal carers to produce care is taken into account. 'Rather than starting by looking at what people are entitled to according to regulations, we will first look at what people can do themselves and how their personal environment can support them.' (P10, p.20). This entails an increase in the role of informal carers and volunteers and regular producers are made responsible for determining the amount of personal resources that is required from people and their environments in particular cases. Citizen action is portrayed as something that could be deployed by governments and/or should be expanded.

Dedication and commitment from informal carers is needed and counted upon in the context of the transition of the care system (P6, p.5). Besides being important for enhancing well-being, informal care contributes indirectly to keeping the care provided by regular providers affordable, durable and of high quality. In this sense, professional carers "lean" on the contribution of informal carers to the care provision. In this respect, professionals, together with local governments, play a pivotal role in activating people and their social network: "To provide customized care, professionals start the conversation about the help request and the opportunities for self-management and self-reliance and the deployment of the social network of people." (P10, p.23) The idea here is that if more people become 'activated', the care provided by other (informal) carers becomes more diluted and thus manageable (P33, p.8). In this narrative, national government addresses citizens not as 'clients' or 'service users' but as 'citizens'. Here, encouraging active citizenship comes strongly to the fore. Both people in need and their environment are 'activated' to become active in the production of their care, while the role of regular care providers is framed to become smaller, though they have a task in mobilising citizens' resources.

As the resources of citizens are framed as being an inextricable part of the care system, of which local governments eventually remain responsible, this narrative clearly emphasises the importance of activating citizens in a process of co-production. For regular care providers this implies a mobilizing and connecting role. The total amount of care is co- produced by regular and citizen providers.

\section{Supportive narrative}

Within the support narrative, governments work on creating a favourable and supportive policy climate for facilitating informal care provision. In formulating policy goals, government aims to support informal 
carers: a very prominent narrative, coming to the fore in $86 \%$ of the analysed policy documents. Furthermore, the supportive narrative is dominating the discourse in $38 \%$ of the policy documents $(14$ of 37).

As governments increasingly rely upon informal carers' efforts in care provision, informal-carer overload, which reduces their long-term deployment, should be prevented (P9, p.4). In supporting informal carers, both local governments and regular care providers play crucial roles. The law stipulates that local governments are responsible to arrange customized support infrastructures for informal carers (P33, p.8). 'A well-designed local support infrastructure should alleviate informal carers' (P8, p.7). While people can still rely on professional care, this type of care is provided in collaboration with the people themselves and their environments. In this process regular care providers should eye for the needs of informal carers and support them (P6, p.2; P8, p.12; P14, p.7). For regular care professionals, "this implies a different attitude" and a "professional development". Identifying needs of and supporting informal carers have become part of the new competences of professionals (P5, p.7). Professionals could for instance capacitate informal carers in taking specific care measures (e.g. P1, p.3). In this narrative, the relationship between citizens and government is framed as a co-production: citizens are addressed as important care producers (informal care providers), while regular providers should capacitate and facilitate them. This implies that regular care providers are not only responsible for activating citizens, they should also support citizens in their attempts to provide care.

\section{Partnership narrative}

Teamwork between informal and formal carers is key within the partnership narrative. 'It is all about person-centred care in partnerships' (P32, p.2). This narrative is present in $81 \%$ of policy documents. However, only in $5 \%$ of the cases ( 2 of 37 ) the partnership narrative is dominant. Just like the 'activation' narrative, this narrative plays a supporting and complementing role in the overall framing in the document.

The specific definition that national governments use to define partnership in this narrative is that professionals act as back-up care providers when informal care provided by family and volunteers is insufficient. 'When someone is insufficiently helped with the deployment of his/her own power/resources and 
with the help of other people in his/her family and social network, the municipality will provide individual customized care' (P18, p.7). Thereby, professionals complement the informal care provision of individuals instead of the other way around.

Actual interaction and teamwork, instead of a mere complementing partnership, is stressed in relation to the formal drafting of a care plan. Here, the national government talks about explicitly institutionalizing the involvement of informal carers in the examination of individual requests for social support (P6, p.4). By strengthening the formal position of informal carers, government tries to create a level playing field: 'Professionals should see informal carers and volunteers as equal partners in care provision' (P8, p.12).

\section{Competitive narrative}

Interestingly, the competitive narrative in which self-organized citizen service provision is presented as the alternative to current governmental care services is present in only $11 \%$ of policy documents (4 of 37). In none of these documents the competitive narrative dominates.

Within the competing narrative, citizens are depicted as direct competitors of regular providers as they can compete for the same care budgets ('parallel production'). In order to 'self-organize care services' (P37, p.6), citizens can for instance set up care cooperatives (P14, p.5) or avail of the Right to Challenge. Here, 'community groups and social enterprises can bid to run governmental care services where they believe they can do so differently and better than the currently provided services' (P14, p.4). The role of governments in the framing is to remove possible obstacles for self-organization and facilitate the further activation of citizens (P14, p.4). In order to foster the connective capacity of governments to societal initiatives, the national government started an experiment program to explore how requirements can be made more in line with societal initiatives and how municipal procurement procedures can be made more open to those initiatives (P12, p.7; P29, p.5). How government positions the role of professionals towards these competitors remains unclear though. Being only marginally addressed, this narrative on self-organization gets less attention than the co-production narratives in which the activation of citizens takes place within the control of regular service providers. 


\section{Client narrative}

The most dominant narrative in the policy documents is the client narrative. This narrative is present in $68 \%$ of the policy documents, of which in $51 \%$ it is the dominant narrative (19 of 37). Thus, in more than half of the analysed documents the responsibility for care provision is clearly attributed to professionals, healthcare institutions and local governments. In this narrative citizens are framed as clients or patients. In contrast to the other narratives, future proof and high-quality care is framed to be the responsibility of board members of care institutions and/or professionals (P32, P.2). For example when it comes to future proof care in nursing homes: "the fundamental change is in the relationship between clients and professionals." (P30. P.4) There is little consideration of the ways in which either service users themselves might co-produce their own care improvements with professionals (e.g. by using tele care facilities or by participating in health improvement or through behaviour change programmes) or the ways in which volunteers might help to improve outcomes of existing public care programmes (e.g through peer support activities). Since these have both become major components of care programmes across OECD countries in the past decade, this finding is interesting.

In contrast to the previous narratives citizens are addressed as (passive) clients. Within the client narrative other citizens are addressed than within the supportive, partnership and competitive narratives. In this narrative governments focuses on citizens who are not self-reliant, while in the other narratives their families and volunteers are addressed. 
TABLE 3 Overview narratives

\begin{tabular}{|c|c|c|c|}
\hline Narratives & $\begin{array}{l}\text { Results: percentage } \\
\text { and amount of } \\
\text { documents containing } \\
\text { the code }\end{array}$ & $\begin{array}{l}\text { Results: percentage } \\
\text { and amount of } \\
\text { documents where } \\
\text { code was dominant }\end{array}$ & Description \\
\hline Activation narrative & $68 \%(25 / 37)$ & $5 \%(2 / 37)$ & $\begin{array}{l}\text { Citizens are } \\
\text { activated to } \\
\text { become co- } \\
\text { producers, } \\
\text { providers as } \\
\text { coordinators. }\end{array}$ \\
\hline Supportive narrative & $86 \%(32 / 37)$ & $38 \%(14 / 37)$ & $\begin{array}{l}\text { Citizens are framed } \\
\text { as co-producers, } \\
\text { providers as } \\
\text { facilitators and } \\
\text { supporters. }\end{array}$ \\
\hline Partnership narrative & $81 \%(30 / 37)$ & $5 \%(2 / 37)$ & $\begin{array}{l}\text { Citizens are framed } \\
\text { as co-producing } \\
\text { partners, providers } \\
\text { as back-up care } \\
\text { providers. }\end{array}$ \\
\hline Competing narrative & $11 \%(4 / 37)$ & $0 \%(0 / 37)$ & $\begin{array}{l}\text { Citizens take } \\
\text { responsibility and } \\
\text { ownership of care } \\
\text { process. }\end{array}$ \\
\hline Client narrative & $68 \%(25 / 37)$ & $51 \%(19 / 37)$ & $\begin{array}{l}\text { Citizens are framed } \\
\text { as clients. } \\
\text { Providers are } \\
\text { regulating and } \\
\text { producing care } \\
\text { services. }\end{array}$ \\
\hline
\end{tabular}

1 The narrative that covers the highest number of sentences, is considered to be dominant within a document. Therefore, there can only be one dominant narrative per document

\section{Time trend?}

When we divide the 37 documents in four piles (of around 9 documents per pile) to take the timing of narratives into account, we can observe corresponding supportive and client narratives. Although it should be noted that the time scope of the sample is quite small for discovering any meaningful time trends, we do observe some differences between the four quarters (see table 4). While in the beginning of the reform the supportive narrative dominated, the client narrative convincingly took over in the middle of the reform (second and third quarter). The last documents showed a converging of the two narratives: both are 
strongly present and either one of them being the dominant one. It seems government has found a balance between both narratives in the end of the examined reform period.

TABLE 4 Time trend

\begin{tabular}{llllll}
\hline $\begin{array}{l}\text { Documents } \\
\text { divided in 4 } \\
\text { quarters }\end{array}$ & $\begin{array}{l}\text { Activation } \\
\text { narrative }\end{array}$ & $\begin{array}{l}\text { Supportive } \\
\text { narrative }\end{array}$ & $\begin{array}{l}\text { Partnership } \\
\text { narrative }\end{array}$ & $\begin{array}{l}\text { Competitive } \\
\text { narrative }\end{array}$ & $\begin{array}{l}\text { Client } \\
\text { narrative }\end{array}$ \\
\hline $\begin{array}{l}\text { First-quarter } \\
(2012-2013)\end{array}$ & 1 & 5 & 1 & 2 \\
$\begin{array}{l}\text { Second-quarter } \\
(2013-2014)\end{array}$ & & 3 & 1 & 5 \\
$\begin{array}{l}\text { Third-quarter } \\
(2014-2015)\end{array}$ & & 2 & & 7 \\
$\begin{array}{l}\text { Fourth-quarter } \\
(2015)\end{array}$ & 1 & 4 & & 5 \\
\hline
\end{tabular}

\section{Discussion}

Although our analysis shows that although the client narrative is dominant in half of the analysed policy documents, the overall picture shows a strong focus on activating, supporting and partnering with citizens. These narratives on citizens as active service producers are used in more documents than the narrative on citizens as passive client: $95 \%$ against $68 \%$. Citizens are framed as active services producers which are and should be part of the general system of care service delivery. We could not find clear patterns in the joint occurencences of narratives; the national government uses multiple narratives frequently and freely throughout the policy documents. This expansion and diversification of accompanying roles for regular providers seems to be, at least in this particular policy area, a significant change from previous providercentric inspired frames.

As noticed, the framing of citizens as active service producers in care service provision comes to the fore in different narratives. In the activation narrative, governments cast citizens as (informal) carers and try to incorporate them in the formal system by indicating that they count upon their commitment. By making use of this narrative, the national government calls for the activation of citizens in the care sector. In this process of becoming active co-producers of care, local governments and professionals are there to support citizens. This is key within the supportive narrative, where informal carers are again portrayed as being the main provider of home care. Interestingly, instead of facilitating collective forms of citizen activation, 
the focus is rather on individual citizens as informal carers and in this role, as implementers of care services. The authority in the co-production relationship explicitly remains at the governmental side in the narratives. The form in which citizens organize their own care in a civic collective outside the direct realm of government, is only marginally addressed: in $11 \%$ of the documents. Additionally, we did not found, for example, a facilitative frame in which government seeks to stimulate and facilitate citizen groups in organizing care for their community, giving them more democratic control and ownership, as suggested by scholars and government scientific advisory boards oriented at democratic innovation (e.g. Wagenaar and Van der Heijden, 2015; ROB, 2012). In line with the literature on co-production, it seems that the activation of citizens is predominantly seen as a means to enhance the efficiency and effectiveness of public governance, and not so much to enhance citizens' democratic influence (cf. Voorberg et al., 2015).

In the partnership narrative, professionals and informal carers are portrayed as partners, who should cooperate and adapt their efforts in providing care for individuals. However, how the actual interaction take shape and how long term relationships are built remains unclear. Indeed, in this process of cooperation and adaptation, regular providers are framed as being the 'back-up' service providers. Namely, if the production efforts of citizens fail, local governments are obliged to intervene as maintaining a good level of care remains a government responsibility. Therefore, the question is whether this process of 'partnering' implies a process of co-producing public care services and what kind of co-production. As far as it concerns interaction between citizens and professionals in the design and production of public services, this interaction seems to take place in a quite vertical manner rather than a horizontal one. Government explicitly states that it decides where responsibility should shift towards citizens and where not. This finding support claims of authors suggesting that governments are co-opting citizen action in their policy agendas and thereby trying to reshape those with whom they collaborate (e.g. Brandsen et al., 2014; Newman, 2007).

As becomes clear, these narratives are strongly connected and complement one another. They are aimed at giving shape to a shared delivery of care services by trying to incorporating the efforts of informal carers in the formal system by activation, supporting and cooperating with citizens. In this way, the national governments place the efforts of citizens under a shadow of hierarchy. 


\section{Conclusions}

In this article we empirically examined the framing of the relationship between citizens and regular service providers in recent care reforms in the Netherlands, contributing to wider understanding of changing relationships in care provision. This responds to recent calls to make the research into co-production methodically more diverse and to pay more attention to studying the role of regular service providers (Brandsen \& Honingh, 2016).

Based on a content analysis of policy documents on the provision of care services in the period 2012-2015, this study shows that the Dutch national government seeks to activate individual citizens (and their families) in the implementation of care services. By making use of activation, supportive, partnership and competing narratives, the government reshapes traditional roles. These findings provides empirical back up for the claim that co-production and self-organization in the public sector is becoming an increasingly important theme (e.g. Voorberg et al., 2015; Edelenbos and Van Meerkerk, 2016), at least when it concerns the governmental discourse about care reforms: a policy sector that is traditionally characterized by strong levels of government responsibility and activity. However, these newer roles (citizen-as-co-producers) do not substitute traditional roles (citizen-as-clients), but constitute a new, additional layer resulting in an expansion and diversification of roles for regular providers.

With regards to the wider understanding of changing care provision this study demonstrates that the national government is calling for a new public service ethos of professionals. In recent care reforms the central role of professionals is portrayed to encompass the mobilization, support and coordination of the co-production capabilities of the social network of service users. The described diversification of roles in co-producing care services with informal carers implies a versatile role for regular service providers. Next to their more traditional role as service provider (client narrative), professionals now have to activate the social network of people in need (activation narrative), support these informal carers in providing care (supportive narrative) while taking part in a collaborative process with them (parthership narrative). The aim of this reform essentially comes down to cutback expenditures to ensure the affordability and accesssiblity of the care-system by reducing the overall activities and role of professionals. This indicates a 
fundamental transformation in the relations of care service provision. In this respect, Endo and Lim (2017: 294) argue that the current transformation of the welfare state seeks to privatise the delivery of services to the third sector while the state maintains public responsibility for citizen's social rights.

It is important to put our conclusions into perspective. Although we have been able to elucidate how national governments frame the new co-production roles of citizens and professionals, this knowledge is based upon national policy letters in one country from a relatively small period in time. An interesting aspect for follow-up research concerns comparison of governmental framing across different timeframes (within countries) and/or comparing the framing of governments across different countries. A comparative country study could elucidate whether the same frames are found in countries with similar and with different governance traditions (cf. Pollit and Bouckaert 2011). Furthermore, it is good to keep in mind that the consequences of the identified narratives for actual service delivery have to be established. Do citizens recognize themselves in the governmental framing of their role as self-organizing partners of government? And does this framing affect their perception and their interpretation of their role? Do professionals take up their role as activator, partner and supporter? These are important questions for future research. Focussing on citizen production of care services fundamentally changes the roles not only of citizens, but also of professionals, as government requires care professionals to take up multiple roles simultaneously. Whereas in discursive practices all types of narratives can peacefully coexist, it might well be that, in policy practice, various conflicts and tensions arise as a result of incompatible roles. The practical implications of this hybridization of roles thus have to be established.

\section{Acknowledgements}

We would like to thank Erik Hans Klijn and the anonymous reviewers for their feedback on earlier versions of this article. Furthermore we would like to thank researchers of the Repolis Research Program (Erasmus University Rotterdam), EGPA Civil Society, Citizens and Government panel (2016) and the IRSPM New Researchers panel (2016). We are grateful for the extensive and constructive comments we received there. Last but not least we would like to thank Rianne Dekker for her help with the methodology of the article. 


\section{References}

Boeije, H. 2002, A purposeful approach to the constant comparative method in the analysis of qualitative interviews, Quality \& Quantity 36, 391-409.

Borghi, V. and Van Berkel, R. 2007, Individualised service provision in an era of activation and new governance, International Journal of Sociology and Social Policy, 27, 9/10, 413-424.

Bovaird, T. 2007, Beyond engagement and participation: User and community co-production of public services, Public Administration Review, 67, 5, 846-860.

Bovaird, T., Van Ryzin, G.G., Loeffler, E. and Parrado, S. 2015, Activating Citizens to Participate in Collective Co-production of Public Services. Journal Social Policy, 44, 1, 1-23.

Brandsen, T., Trommel, W. and Verschuere, B. 2014, Manufactured Civil Society: Practices, Principles and Effects, Basingstoke: Palgrave Macmillan.

Brandsen, T. and Honingh, M. 2016, Distinguishing different types of co-production: a conceptual analysis based on the classical definitions, Public Administration Review, 76, 3, 427-435.

Brudney, J.L. 1983, The Evaluation of Co-production Programs, Policy Studies Journal, 12, 2, 376.

Bryson, J.M., Barbare, C.C. and Bloomberg, L. 2014, Public Value Governance: moving beyond traditional public administration and the new public management, Public Administration Review, $74,4,445-56$.

Edelenbos, J., van Meerkerk, I., \& Koppenjan, J. 2017, The challenge of innovating politics in community selforganization: the case of Broekpolder, Public Management Review, 19, 1, 55-73.

Edelenbos, J., and I. F. van Meerkerk, eds. 2016, Critical Reflections on Interactive Governance. SelfOrganization and Participation in Public Governance. Cheltenham: Edward Elgar Publishers.

Endo, C. and Lim, S.H. 2017, Devolving public duties: can the social economy fultil social rights? Policy \& Politics, 45, 2, 287-302.

Hajer, M. 2003, A Frame in the Fields: Policy making and the Reinvention of Politics, in: H. Wagenaar and M. Hajer (eds) Deliberative Policy Analysis: Understanding Governance in the Network Society, Cambridge: Cambridge University Press.

Hayes, A.F. and Krippendorff, K. 2007, Answering the Call for a Standard Reliability Measure for Coding Data, Communication Methods and Measures, 1, 77-89.

Healey, P. 2015, Citizen-generated local development initiative: recent English experience, International 
Journal of Urban Sciences, 19, 2, 109-118.

Künzel, S. 2012, The local dimension of active inclusion policy, Journal of European Social Policy, $22,1,3-16$.

Lodge, M. and Hood, C. 2012, Into an age of multiple austerities? Public management and public sector bargains across OECD countries, Governance, 25, 1, 79-101.

Movisie, 2015, Wijzigingen AWBZ en Wmo: een overzicht. https://www.movisie.nl/artikel/wijzigingenawbz-wmo-overzicht

Newman, J. 2007, The "double dynamics" of activation: Institutions, citizens and the remaking of welfare Governance, International journal of sociology and social policy, 27, 9/10, 364-375.

Oorschot, W. van, 2006, The Dutch Welfare State: Recent Trends and Challenges in Historical Perspective, European Journal of Social Security, 8, 1, 57-76.

Osborne, S.P. and Strokosch, K. 2013, It takes two to tango? Understanding the co-production of public services by integrating the services management and public administration perspectives, British Journal of Management, 24, 31-47.

Pestoff, V., 2006, Citizens as co-producers of welfare services: preschool services in eight Europen Countries, Public Management Review, 8, 4, 503-20.

Pestoff, V. 2012, Co-production and third sector social services in Europe. Some crucial conceptual Issues, in V. Pestoff, T. Brandsen and B. Verschuere (eds) New Public Governance, the Third Sector and Co-production (chapter 2), London: Routledge.

Pollitt, C., \& Bouckaert, G. 2011, Public Management Reform: A comparative analysis-new public management, governance, and the Neo-Weberian state. New York: Oxford University Press.

Raad voor het openbaar bestuur (Rob) 2012, Loslaten in vertrouwen: Naar nieuwe verhoudingen tussen overheid, markt én samenleving, The Hague: Rob.

Rose, N. 2006, Governing “advanced” liberal democracies', in A. Sharma and A. Gupta (eds.), The Anthropology of the State, London: Blackwell, 144-62.

Strauss, A.L. and Corbin, J. 1990, Basics of Qualitative Research: Grounded Theory Procedures and Techniques, Sage.

Thomas, G. 2011, A typology for the case study in social science following a review of definition, discourse, and structure, Qualitative inquiry, 17, 6, 511-521. 
Thomas, J. C. 2013, Citizen, Customer, Partner: Rethinking the Place of the Public in Public Management, Public Administration Review, 73, 6, 786-796.

Van Meerkerk, I., Boonstra, B., \& Edelenbos, J. 2013, Self-organization in urban regeneration: A two-case comparative research, European Planning Studies, 21, 10, 1630-1652.

Verhoeven, I., and Tonkens, E. 2013, Talking active citizenship: framing welfare state reform in England and the Netherlands, Social Policy and Society, 12, 3, 415-426.

Verschuere, B., Brandsen, T. and Pestoff, V. 2012, Co-production: the state of the art in research and the future agenda, Voluntas: International Journal of Voluntary and Nonprofit Organizations, $23,4,1083-1101$.

VNG, 2015, Hervorming Langdurige Zorg 2014 https://vng.nl/onderwerpenindex/maatschappelijkeondersteuning/wmo-2015/wetstraject-wmo-2015

Voorberg, W.H., Bekkers, V.J.J.M. and Tummers, L.G. 2015, A systematic review of co-creation and co-production: embarking on the social innovation journey, Public Management Review, 17, 9, 1333-1357.

Wagenaar, H. and Van der Heijden, J. 2015, The Promise of Democracy? Civic Enterprise, Localism and the Transformation of Democratic Capitalism, in S. Davoudi and A. Madanipour (eds) Reconsidering Localism, Abingdon: Routledge, 126 - 146.

Yerkes, M., Achterberg, P. and Van Der Veen, R. 2011, The Transformation of Solidarity, Amsterdam: Amsterdam University Press. 


\section{Appendix}

TABLE A

\begin{tabular}{|c|c|c|c|}
\hline Department & Title of policy document in Dutch [and English] & Year & P (ID) \\
\hline Ministerie van VWS & Policy letter family care & 2012 & 1 \\
\hline Ministerie van VWS & Loneliness & 2012 & 2 \\
\hline Ministerie van VWS & Implementation action plan 'elderly in safe hands' & 2012 & 3 \\
\hline Ministerie van VWS & $\begin{array}{l}\text { Progress report autumn } 2012 \text { 'violence in dependency } \\
\text { relationships' }\end{array}$ & 2012 & 4 \\
\hline Ministerie van VWS & Vision on the care and welfare labour market & 2013 & 5 \\
\hline Ministerie van VWS & Progress 'Strengthening, facilitating and linking' & 2013 & 6 \\
\hline Ministerie van VWS & Investing in palliative care & 2013 & 7 \\
\hline Ministerie van VWS & Strengthening, facilitating and linking & 2013 & 8 \\
\hline Ministerie van SZW & Results meeting work and care of November 18 & 2013 & 9 \\
\hline Ministerie van VWS & Shared agenda VWS 'From systems to people’ & 2013 & 10 \\
\hline Ministerie van VWS & Consideration Social Support Act 2015 & 2014 & 11 \\
\hline Ministerie van EZ & Autumn report on regulatory burdens & 2014 & 12 \\
\hline Ministerie van VWS & $\begin{array}{l}\text { Intensifying and institutionalizing the approach to } \\
\text { loneliness }\end{array}$ & 2014 & 13 \\
\hline Ministerie van BZK & $\begin{array}{l}\text { Reaction to the motion put forward by Mr Slob regarding } \\
\text { the participation society }\end{array}$ & 2014 & 14 \\
\hline Ministerie van BZK & $\begin{array}{l}\text { Targeting restrictive rules for volunteers and citizen } \\
\text { participation }\end{array}$ & 2014 & 15 \\
\hline Ministerie van VWS & Short-term primary residence & 2014 & 16 \\
\hline Ministerie van VWS & $\begin{array}{l}\text { Short-term residential care in AWBZ, Wmo 2015, Zvw, } \\
\text { Youth Act and Wlz }\end{array}$ & 2014 & 17 \\
\hline Ministerie van BZK & $\begin{array}{l}\text { Transition Agenda for living independently for a longer } \\
\text { time }\end{array}$ & 2014 & 18 \\
\hline Ministerie van VWS & Coherence in care and welfare & 2014 & 19 \\
\hline Ministerie van VWS & Transition reforming long-term care & 2014 & 20 \\
\hline Ministerie van VWS & $\begin{array}{l}\text { The Wmo in motion; Evaluating the Social Support Act } \\
2010-2012\end{array}$ & 2014 & 21 \\
\hline Ministerie van VWS & Outcomes budgetary conciliations long-term care reforms & 2014 & 22 \\
\hline Ministerie van VWS & Waiting lists care and nursing homes & 2014 & 23 \\
\hline Ministerie van VWS & Progress letter on informal care & 2014 & 24 \\
\hline Ministerie van VWS & Progress transition Wmo 2015 & 2014 & 25 \\
\hline Ministerie van VWS & Progress report HLZ & 2014 & 26 \\
\hline Ministerie van VWS & $\begin{array}{l}\text { Commission letter of the Second Chamber in response to } \\
\text { NOS.nl dated } 13 \text { April } 2015 \text { 'Older people get too little } \\
\text { care at home' }\end{array}$ & 2015 & 27 \\
\hline Ministerie van VWS & $\begin{array}{l}\text { Request from the Regulation of work to respond to the } \\
\text { SCP research 'Competition between informal care and } \\
\text { paid work' in response to the message 'Participation } \\
\text { society takes its toll in the workplace' (Volkskrant, } 24 \\
\text { March 2015) }\end{array}$ & 2015 & 28 \\
\hline Ministerie van BZK & Transformation in the social domain & 2015 & 29 \\
\hline Ministerie van VWS & $\begin{array}{l}\text { Elaboration of the quality letter of elderly care: 'Dignity } \\
\text { and pride. Loving care for our elderly' }\end{array}$ & 2015 & 30 \\
\hline Ministerie van BZK & $\begin{array}{l}\text { Progress report Transition agenda living independently } \\
\text { for a longer time }\end{array}$ & 2015 & 31 \\
\hline Ministerie van VWS & Dignity and pride & 2015 & 32 \\
\hline Ministerie van VWS & Living with dementia & 2015 & 33 \\
\hline Ministerie van VWS & $\begin{array}{l}\text { Intention expiration WTZi-requirement for respite care in } \\
\text { Wlz }\end{array}$ & 2015 & 34 \\
\hline
\end{tabular}


Ministerie van VWS

Ministerie van VWS

isterie van VWS
Progress report Informal Care

Progress report transition HLZ

Renewal letter care and welfare close to home
2015

2015

2015
35

36

37 